\title{
Empirical Study on the Degree of Coupling Coordination Between Ice-snow Tourism and Cultural Industry Integration Take Harbin as An Example
}

\author{
Zhang Xiaofeng ${ }^{1 *}$, Lu Shiyu ${ }^{1}$ \\ ${ }^{1}$ School of Finance and public administration, Harbin University of Commerce, Harbin, Heilongjiang 150028
}

\begin{abstract}
Harbin is the capital of Heilongjiang Province in China, the ice-snow tourism industry develops rapidly. How to integrate with the cultural industry and cultivate a new growth point of Harbin is a hot research area. Harbin culture and tourism industry has a good foundation, the development of industry integration accelerates and infrastructure is increasingly perfect. However, it also faces some practical problems, such as the lack of the depth of industrial resources exploitation and utilization efficiency, the low integration degree of ice-snow tourism and cultural industry chain, and the lack of cultural products of highend music and painting leisure tourism. Build a coupling and coordination model and have a empirical analysis of the degree of coupling coordination between Harbin's ice-snow tourism and cultural industry integration, the conclusion is that the coupling coordination is low and the development of cultural industry lags behind.
\end{abstract}

\section{Introduction}

Harbin is the capital of Heilongjiang Province, with many geographical and cultural advantages, which also determine that Harbin Ice-snow tourism has a solid foundation and unique conditions. From the data of icesnow tourism in recent years, we can see that Harbin's tourism industry is developing very rapidly, and has a well popularity and reputation. Harbin has a rich variety of tourism products, including Ice-snow World, ice lantern exhibition, snow sculpture exhibition, Ice-snow paradise, skating and skiing, curling and other entertainment ways and places. It is well-known at home and abroad, attracting countless tourists to watch and experience, making Harbin a famous tourism city with ice -snow projects as the main body in China. It is precisely because of the advantages of ice and snow that we can develop ice-snow tourism industry, so as to drive the development of other industries, inject vitality into the economic development of Harbin and make the economy develop continuously. Ice-snow culture has a great impact on Harbin's urban construction, If we want to develop Harbin Ice -snow tourism industry well, we should pay attention to its connotation development, especially the development of ice-snow industry culture connotation. To show and promote Harbin Ice-snow tourism industry from the perspective of culture can get twice the result with half the effort. Integrating the black land culture into the ice-snow tourism project can more effectively attract domestic and foreign tourists and improve the influence of Harbin Ice-snow tourism. Adhering to the connotative development road can integrate the ice-snow tourism industry into the multi culture, integrate the ice-snow tourism resources in Harbin, make it play a greater advantage, attract more tourists, obtain higher economic benefits, drive the development of other industries, and constantly promote the better and faster development of ice-snow tourism industry in Harbin.

\section{Calculation of coupling coordination degree between ice-snow tourism and cultural industry in Harbinigures}

\subsection{Index selection and its weight}

According to the principles of representativeness, systematicness, scientificity, and availability of indicators, 8 indicators of Harbin ice-snow tourism industry and cultural industry are selected, with a total of 16 indicators. Using $U_{1}$ represents the overall development index of ice-snow tourism industry, $\mathrm{U}_{2}$ represents the general index of cultural industry development. The specific index, unit and weight are shown in Table 1 should be typed in 9-point Times.

Table1 Evaluation index of coupling coordination degree between ice-snow tourism and cultural industry in Harbin

\begin{tabular}{|c|c|c|c|}
\hline $\begin{array}{c}\text { Syst } \\
\text { em }\end{array}$ & Index & Explain & Weight \\
\hline \multirow{2}{*}{$\mathrm{U}_{1}$} & $\begin{array}{c}\text { Domestic ice-snow } \\
\text { tourism revenue (100 } \\
\text { million yuan) }\end{array}$ & $\begin{array}{c}\text { Economic benefits } \\
\text { of ice-snow tourism } \\
\text { in Harbin }\end{array}$ & 0.0921 \\
\cline { 2 - 4 } & \multicolumn{2}{|c|}{${ }^{2}$} &
\end{tabular}




\begin{tabular}{|c|c|c|c|}
\hline & $\begin{array}{l}\text { Domestic ice-snow } \\
\text { tourists (10000 people) }\end{array}$ & $\begin{array}{c}\text { Scale of domestic } \\
\text { tourist market in } \\
\text { Harbin } \\
\end{array}$ & 0.0609 \\
\hline & $\begin{array}{l}\text { International Ice-snow } \\
\text { tourism revenue (100 } \\
\text { million US dollars) }\end{array}$ & $\begin{array}{l}\text { Harbin ice-snow } \\
\text { tourism foreign } \\
\text { exchange earning } \\
\text { capacity }\end{array}$ & 0.1379 \\
\hline & $\begin{array}{l}\text { International ice-snow } \\
\text { tourists (10000 people) }\end{array}$ & $\begin{array}{c}\text { Scale of } \\
\text { international tourist } \\
\text { market in Harbin }\end{array}$ & 0.0491 \\
\hline & $\begin{array}{l}\text { Grade A ice-snow } \\
\text { tourist attractions }\end{array}$ & $\begin{array}{l}\text { The richness of ice- } \\
\text { snow tourism } \\
\text { resources in Harbin }\end{array}$ & 0.0361 \\
\hline & $\begin{array}{l}\text { Tourist attractions } \\
\text { above 4A level }\end{array}$ & $\begin{array}{l}\text { Quantity of high } \\
\text { quality ice and } \\
\text { snow tourism } \\
\text { resources in Harbin }\end{array}$ & 0.0674 \\
\hline & $\begin{array}{c}\text { Number of hotels above } \\
\text { three stars }\end{array}$ & $\begin{array}{c}\text { The scale of } \\
\text { accommodation } \\
\text { industry in Harbin }\end{array}$ & 0.0761 \\
\hline & $\begin{array}{l}\text { Proportion of catering } \\
\text { and accommodation in } \\
\text { project construction } \\
\text { investment }(\%)\end{array}$ & $\begin{array}{c}\text { Investment scale of } \\
\text { catering and } \\
\text { accommodation in } \\
\text { Harbin }\end{array}$ & 0.0729 \\
\hline \multirow{8}{*}{$\mathrm{U}_{2}$} & $\begin{array}{c}\text { TV program coverage } \\
\text { rate }(\%)\end{array}$ & \multirow{2}{*}{$\begin{array}{l}\text { The profound } \\
\text { influence of Harbin } \\
\text { Telecom on Culture }\end{array}$} & 0.0809 \\
\hline & $\begin{array}{c}\text { Radio, film and } \\
\text { television coverage rate } \\
(\%)\end{array}$ & & 0.0807 \\
\hline & $\begin{array}{l}\text { Number of cultural } \\
\text { venues (seats) }\end{array}$ & \multirow{4}{*}{$\begin{array}{l}\text { Hardware facilities } \\
\text { level of Harbin } \\
\text { cultural industry }\end{array}$} & 0.0302 \\
\hline & $\begin{array}{l}\text { Number of Public } \\
\text { Libraries }\end{array}$ & & 0.0329 \\
\hline & $\begin{array}{l}\text { Number of books in the } \\
\text { library }(10000)\end{array}$ & & 0.0709 \\
\hline & $\begin{array}{l}\text { Cultural stations in } \\
\text { villages and towns }\end{array}$ & & 0.0558 \\
\hline & $\begin{array}{l}\text { Service consumption } \\
\text { and price growth of } \\
\text { cultural goods }(\%)\end{array}$ & \multirow{2}{*}{$\begin{array}{l}\text { The effective } \\
\text { demand of Harbin } \\
\text { cultural market. }\end{array}$} & 0.0059 \\
\hline & $\begin{array}{c}\text { Proportion of cultural } \\
\text { investment in project } \\
\text { construction investment } \\
(\%)\end{array}$ & & 0.0502 \\
\hline
\end{tabular}

\subsection{Data sources and processing}

Data sources. This topic selects the relevant data of Harbin from 2011 to 2019, mainly from the statistical yearbooks of Harbin, Heilongjiang, China, China Tourism and Chinese cultural relics, as well as the public websites of Harbin Bureau of statistics, Heilongjiang Provincial Bureau of statistics and relevant governments.

Data processing. According to the above selected indicators, according to the annual data order, the initial data matrix needs to be constructed, as follows.

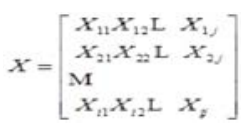

In the above publicity, $i$ represents the year, $j$ represents the number of indicators, Xij represents the $\mathrm{j}$ th index value in the $\mathrm{i}$-th year. This topic needs to establish the coupling coordination degree model of icesnow tourism and cultural industry. The selected indicators include positive and negative indicators. The extreme value method is used to deal with the dual indicators differently, and 0.01 is added to the index data to ensure that the calculated data is meaningful. Here Xij expressed as $X^{\prime} i_{j}$, This standard value after dimensionless is between $0-1$, and the value range is directly proportional to the contribution. If it is 1 , it reaches the maximum value.

\subsection{Constructionata of coupling coordination degree model}

$\mathrm{U}_{1}$ and $\mathrm{U}_{2}$ 's comprehensive evaluation index of the development level is denoted by $\mathrm{T}$ Which used to determine the development level of $\mathrm{U}_{1}$ and $\mathrm{U}_{2}$. In this paper, the coupling degree is represented by $\mathrm{C}$, which is used to determine the coupling degree $\mathrm{U}_{1}$ and $\mathrm{U}_{2}$. Using $\mathrm{D}$ to express the coupling coordination degree which can not only determine the level of development, but also determine the degree of coordination. The coupling coordination degree model is constructed as follows.

$$
\begin{aligned}
& \mathrm{D}=(\mathrm{T} * \mathrm{C})^{1 / 2} \\
& \mathrm{~T}=\alpha \mathrm{U} 1+\beta \mathrm{U} 2
\end{aligned}
$$

$\alpha$ and $\beta$ are the undetermined coefficients, draw on the previous research results and demonstration, this topic will assign both $\alpha$ and $\beta$ a values of 0.5 .

$$
\begin{aligned}
& \mathrm{C}=2\{[\mathrm{U} 1 * \mathrm{U} 2] /[\mathrm{U} 1+\mathrm{U} 2] 2\} 1 / 2 \\
& \mathrm{U}_{\mathrm{i}=1,2}=\sum_{j=1}^{n} \lambda_{j} \bullet x^{\prime}{ }_{i j}, \sum_{j=1}^{n} \lambda_{j}=1
\end{aligned}
$$

\section{Analysis on the coupling coordination degree of Harbin ice-snow tourism and cultural industry}

\subsection{Evaluation criteria and synchronization}

Evaluation criteria. In order to calculate the coupling coordination degree of Harbin ice-snow tourism and cultural industry, the evaluation standard of coupling coordination degree should be made clear. Based on the method of uniform distribution function and the successful experience of previous studies, combined with the development characteristics and regionalism of ice-snow tourism and cultural industry in Harbin, the coupling coordination dispatching interval is divided into five levels. The specific levels and standards are shown in Table 2

Table 2 Division standard of coupling coordination degree interval and grade

\begin{tabular}{|c|c|c|}
\hline Grade & $\begin{array}{c}\text { Partition } \\
\text { interval }\end{array}$ & Coordination degree \\
\hline 1 & $(0-0.2]$ & Serious maladjustment \\
\hline 2 & $(0.2-0.4]$ & Moderate maladjustment \\
\hline
\end{tabular}




\begin{tabular}{|c|c|c|}
\hline 3 & $(0.4-0.5]$ & Mild maladjustment \\
\hline 4 & $(0.5-0.6]$ & Grudging coordination \\
\hline 5 & $(0.6-0.8]$ & General coordination \\
\hline 6 & {$[0.8-1]$} & High quality coordination \\
\hline
\end{tabular}

Coupling coordination degree and synchronization. This paper not only calculates the degree of coupling coordination to the degree of synergy and closeness of the integration of ice-snow tourism and cultural industry in Harbin, but also further illustrates the synchronization of the integration of the two industries. $\mathrm{P}$ is used to represent the synchronization of the integration of the two industries, and the calculation formula is as follows.

$$
P=\frac{U 1}{U 2}
$$

That is, the synchronism is equal to the comprehensive development index of ice -snow tourism industry $\mathrm{U}_{1}$ divided by the comprehensive development index of cultural industry $\mathrm{U}_{2}$, that is to say, the ratio of

Table 3 Empirical results of coupling coordination degree between ice-snow tourism and cultural industry in Harbin

\begin{tabular}{|c|c|c|c|c|c|c|c|}
\hline Year & $U_{1}$ & $U_{2}$ & $C$ & $D$ & $P$ & $\begin{array}{c}\text { Coordination } \\
\text { degree }\end{array}$ & Synchronicity \\
\hline 2011 & 0.071 & 0.281 & 0.789 & 0.369 & 0.239 & $\begin{array}{c}\text { Moderate } \\
\text { maladjustment }\end{array}$ & $\begin{array}{c}\text { Ice-snow tourism } \\
\text { industry lags behind }\end{array}$ \\
\hline 2012 & 0.098 & 0.271 & 0.891 & 0.411 & 0.369 & $\begin{array}{c}\text { Mild } \\
\text { maladjustment }\end{array}$ & $\begin{array}{c}\text { Ice-snow tourism } \\
\text { industry lags behind }\end{array}$ \\
\hline 2013 & 0.221 & 0.239 & 0.998 & 0.481 & 0.895 & $\begin{array}{c}\text { Mild } \\
\text { maladjustment }\end{array}$ & $\begin{array}{c}\text { Ice-snow tourism } \\
\text { industry lags behind }\end{array}$ \\
\hline 2014 & 0.353 & 0.341 & 0.999 & 0.591 & 1.035 & $\begin{array}{c}\text { Grudging } \\
\text { coordination }\end{array}$ & $\begin{array}{c}\text { Cultural industry } \\
\text { lags behind }\end{array}$ \\
\hline 2015 & 0.261 & 0.331 & 0.994 & 0.541 & 0.883 & $\begin{array}{c}\text { Grudging } \\
\text { coordination }\end{array}$ & $\begin{array}{c}\text { Ice-snow tourism } \\
\text { industry lags behind }\end{array}$ \\
\hline 2016 & 0.223 & 0.292 & 0.994 & 0.499 & 0.761 & $\begin{array}{c}\text { Mild } \\
\text { maladjustment }\end{array}$ & $\begin{array}{c}\text { Ice-snow tourism } \\
\text { industry lags behind }\end{array}$ \\
\hline 2017 & 0.322 & 0.173 & 0.961 & 0.476 & 1.799 & $\begin{array}{c}\text { Mild } \\
\text { maladjustment }\end{array}$ & $\begin{array}{c}\text { Cultural industry } \\
\text { lags behind }\end{array}$ \\
\hline 2018 & 0.296 & 0.091 & 0.843 & 0.466 & 3.511 & $\begin{array}{c}\text { Mild } \\
\text { maladjustment }\end{array}$ & $\begin{array}{c}\text { Cultural industry } \\
\text { lags behind }\end{array}$ \\
\hline 2019 & 0.384 & 0.187 & 0.955 & 0.563 & 2.113 & $\begin{array}{c}\text { Grudging } \\
\text { coordination }\end{array}$ & $\begin{array}{c}\text { Cultural industry } \\
\text { lags behind }\end{array}$ \\
\hline
\end{tabular}

\subsection{Evaluation criteria and synchronization}

According to the above calculation results, a dynamic fitting figure is drawn of the coupling degree of Harbinice-snow tourism and cultural industry(C) Coupling coordination dispatching(D) and synchronization(P), as shown in Figure 1.

Coordination degree analysis. It can be seen from Figure 1 that the coupling degree between ice-snow tourism and cultural industry in Harbin is always at a high level. The coupling degree increased from 0.789 in 2011 to 0.955 in 2019. Except that the coupling degree in 2011, 2012 and 2018 was lower than 0.9, the coupling degree in other years was higher than 0.9 . It can be seen from the data that the coupling degree between Harbin ice-snow tourism and cultural industry presents three obvious stages: in the first stage, from 2011 to 2014, the coupling coordination degree increases year by year, from 0.789 in 2011 to 0.999 in 2014, and the coordination degree develops from moderate maladjustment to grudging coordination; in the second the two is used to explain the synchronization of the two. When $\mathrm{P}<1$, it means that the development of ice- snow tourism industry lags behind; when $\mathrm{P}=1$, it means that the two develop simultaneously; when $\mathrm{P}>1$, It means that the development of cultural industry lags behind.

\subsection{Evaluation criteria and synchronization}

Using the coupling coordination degree model, according to the above calculation formula, the development index of Harbin ice-snow tourism industry $\left(\mathrm{U}_{1}\right)$, Cultural industry development index $\left(\mathrm{U}_{2}\right)$, The comprehensive evaluation index of the two industries(T), Coupling degree of the two industries(C), Coupling coordination degree of two industries(D), Synchronization of the two industries $(\mathrm{P})$ are calculated. The corresponding partition interval and coordination degree are shown in Table 3. stage, from 2014 to 2018, the coupling coordination degree decreases year by year, from 0.789 in 2014 to 0.999 in 2014.In the third stage, in 2018-2019, the coupling coordination degree will rise to 0.955 , and the coordination degree will return from mild maladjustment to grudging coordination.

It can be concluded that the coupling development of Harbin ice-snow tourism and cultural industry integration is a integration process which from maladjustment to coordination, then from coordination to maladjustment, and finally back to coordination. From 2011 to 2013, Harbin ice-snow tourism and cultural industry have little influence on each other and are independent of each other, which belongs to the early stage of integrated development. In 2014, the two industries grew rapidly, and the coupling coordination degree was greatly improved. Even if the coupling coordination degree decreased in 2015 , it was still grudgingly coordinated. In 2016-2018, the ice-snow tourism industry developed rapidly, but the development of cultural industry lagged behind, leading to the 
maladjustment of coupling coordination degree. In 2019, the degree of coupling and coordination between the two industries in Harbin increases significantly, and the icesnow tourism industry and cultural industry both increase significantly.

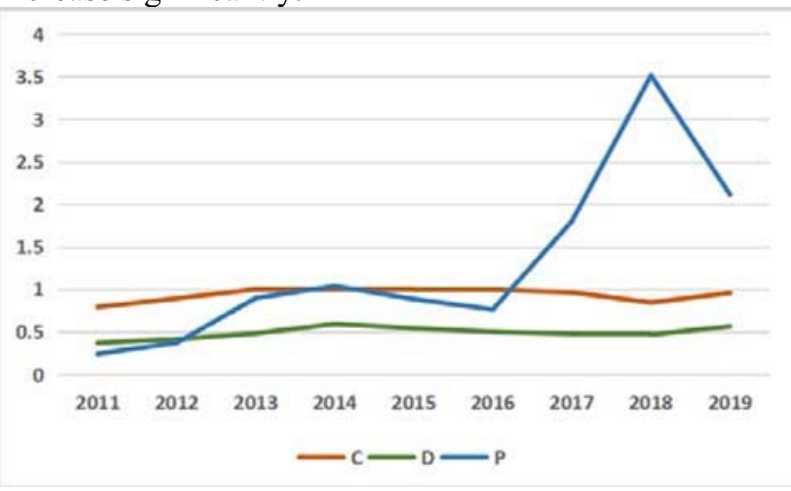

Figure 1 Dynamic fitting diagram of coupling coordination degree between ice-snow tourism and cultural industry in Harbin

Synchronization analysis. It can be seen from Figure 1 that the synchronous change range between ice-snow tourism and cultural industry in Harbin is large. From the perspective of change process, the synchronization can also be divided into three stages: the first stage, from 2011 to 2014, the initial level of cultural industry in Harbin is relatively high, although the development of ice -snow tourism industry is relatively backward, but the development is relatively strong, catching up with the development of cultural industry in 2014.In the second stage, from 2015 to 2016, the ice- snow tourism industry is relatively lagging behind, and the two industries have declined to varying degrees, but the decline of ice-snow tourism industry is more obvious. In the third stage, from 2017 to 2019, the cultural production appeared recession, and the ice-snow tourism industry developed strongly. In 2019, the recession of cultural industry has eased, but the development momentum is not as good as the ice-snow tourism industry.

\section{The conclusion of coupling coordination degree of Harbin ice-snow tourism and cultural industry}

\subsection{Low degree of coupling coordination}

According to the above analysis, from 2011 to 2019, the overall coupling coordination degree of Harbin ice-snow tourism and cultural industry integration development is low. Except for 2014, 2015 and 2019, which are grudgingly coordinated, other years show maladjustment. The specific manifestation is that the coordination and driving effect between ice-snow tourism and culture industry is weak, for example, from 2011 to 2013, Harbin's cultural industry developed rapidly, but it did not promote the rapid development of ice-snow tourism industry. From 2016 to 2018, the growth of ice-snow tourism industry was stable, but the cultural industry did not maintain synchronous growth, and the integration of the two industries was once again maladjusted. Therefore, in order to improve the coupling coordination degree of Harbin ice-snow tourism and cultural industry integration development, we must first strengthen the coordination and driving role between the two industries.

\subsection{The development of cultural industry lags behind}

According to the synchronous analysis of the coupling coordination degree of Harbin ice-snow tourism and cultural industry integration development in Figure 1, since 2014, the development of Harbin cultural industry can't keep up with the development of ice-snow tourism industry, especially in 2016-2019, the development of cultural industry is slow, even declining, seriously lagging behind the rapid development of ice-snow tourism industry, the main reason may be as follows ,First, there are few fiscal and tax incentive policies, even if there are incentive measures, the effect may not be obvious; second, the driving effect of icesnow tourism on the cultural industry is not obvious; third, the problem of the development of the cultural industry itself. Therefore, in order to promote the rapid development of Harbin's cultural industry, and make it integrate with the ice-snow tourism industry, promote each other, and develop together, we must increase the financial and tax incentive policy support, and actively play the leading role of the ice-snow tourism industry. At the same time, the cultural industry should also explore its own problems and improve its healthy and rapid development.

\section{Fund project}

Heilongjiang Province Education Department Ordinary College Young Talents Training Project (UNPYSCT2018126); Heilongjiang government, post-doc program (LBH-Z20162); Harbin university of commerce $\mathrm{PhD}$ research startup fund(2019DS002); Youth innovative talent project Harbin university of commerce (2020CX21).

\section{References}

1. ZiTang. Anintegrated approach to evaluating the coupling coordination between tourism and the environment[J]. Tourism Management,2015,46.

2. Cultural and Creative Industries Concept-A Historical Perspective[J]. Ieva Moore. Procedia Social and Behavioral Sciences. 2014.

3. Allen J. Scott. Cultural-Products Industries and Urban Economic Development: Prospects for Growth and Market Contestation in Global Context[J]. Urban Affairs Review . 2004

4. Li Zaijun. Analysis on the dynamic mechanism and realization path of the integration development of ice-snow industry and tourism industry $[\mathrm{J}]$. China 
Sports Science and technology, 2019,55 (07): 56-62 $+80$

5. Wu Lingmin, Ren Baoguo, He Lixin, Feng Haitao, Lin Zhigang. The effect of Beijing Winter Olympic Games on the development of ice-snow tourism in Beijing, Tianjin and Hebei and the strategy of coordinated promotion [J]. Journal of Beijing Sport University, 2019,42 (01): 50-59

6. Ren Hongmei, Li Xiangju. Analysis on the effect of fiscal and tax policies of cultural industry based on coupling coordination model-Taking Shaanxi Province as an example [J]. Tax economy research, 2018,23 (06): 6 